\title{
DOES TELEVISION PROMOTE DEAGRARIANIZATION? \\ Understanding Rural-Youth Perception Towards the Agricultural-livelihood information on Television
}

\author{
Yogaprasta Adi Nugraha*), David Rizar Nugroho
}

Faculty of Social and Cultural Sciences, Universitas Pakuan, Bogor 16127, Indonesia

*) Email: yogaprasta_adinugraha@unpak.ac.id

Submitted: 16 December 2020 | Accepted: 13 March 2021 | Online publication: 14 March 2021

\begin{abstract}
The phenomenon of the high number of rural-youth migration from rural areas need to be studied from the perspective on how the agricultural livelihood is constructed by actors within the village. This research tries to focus on how rural-youth interpret messages on television about agricultural livelihood. Previous studies have explained that there are several things that can cause youth in the village to migrate out of the village. This study aims to (1) identify the characteristics of youth in Ciasmara Village, Pamijahan District, Bogor Regency, (2) Rural-youth Exposure in watching television. (3) Perceptions of rural youth on agricultural information representations on television. This research was conducted in Ciasmara village, Pamijahan District, Bogor Regency from March 2020 to August 2020 using quantitative research methods with a descriptive-comparative approach. 120 youth were selected as research samples. This research found that some of rural-youth in Ciasmara village admitted to having watched agricultural programs on television either on the news or in other programs in the last six months. The types of agricultural information that rural-youth in Ciasmara village have watched are mostly related to cultivation, harvest failure, pest attacks, and low agricultural prices
\end{abstract}

Kata kunci: agricultural livelihood, migration, rural-youth perceptions, television 


\section{INTRODUCTION}

Indonesia nowadays is facing an unemployment problem for the youth. According to the (BPS, 2017) the number of unemployed youth (aged between 15-24 years old) is twice higher than unemployed adults, while according to the (BPS, 2013) agricultural sector, especially that of people's farming, still played the highest sector to absorb labor compared to other sectors, although the number tended to decrease to 40 percent in 2013. When we look at it more closely, agricultural sector accommodated the highest employment, thirty-two percent of all the youth workforce and 54 percent of the youth workforce in villages (BPS, 2013). Within the last ten years, there has been a great concern about an accelerating decrease in the number of farmer households which reaches 5 million farmer households which is called 'deagrarianization' (Nugraha \& Herawati, 2015). This shows that there is a problem concerning workforce regeneration in the agricultural sector. Youth are no longer interested to work in the agricultural sector. Agricultural sector has a very important position, contributing positively not only to national revenue but also to employment provision in rural areas especially for young workers. Problems of agricultural regeneration have much been discussed, among others by Nugraha \& Herawati (2015), Nugraha (2012) and White (2012). The low rate of youth participation in the agricultural sector becomes a threat to food security in the future. The loss of agricultural regeneration can cause lost generation of farmers, whose condition will affect agricultural production as well as agricultural sustainability. The youth have an important role to determine rural development, since besides an object, they can also play as an active subject to form their identity and to build their preference to work (Huijmans, 2010).

There are many factors that can cause young villagers to migrate to other sectors than agriculture. Some previous studies carried out by Nugraha \& Supriatna (2020), Nugraha (2012), White (2020) mentioned that there are many reasons why young villagers left the agricultural sector: (1) young villagers did not have access to land; (2) the school system tended to expose a negative image of agriculture; (3) there was a problem of agricultural performance; and (4) the social system tended not to support young people to work in the agricultural sector. Although there are some factors that cause young villagers not to get involved in farming, the study will focus on how the agricultural image was formed by the system. Agricultural image or rural jobs cannot be separated from how the social system built or formed the jobs. Nugraha (2012) and White (2012) asserted that one of the fundamental problems for the youth to leave their village is that agricultural jobs are not prestigious, or it is a matter of image. To understand the problem of agricultural sector, which is not prestigious, it is necessary to look at how the position of the main actors around the youth socializes agricultural values. Supriatna \& Nugraha (2020) have explained how the role of agricultural rites builds an agricultural image. However, there has been no research that tries to look in detail how television socializes agricultural values to young people in rural areas.

Ontologically this research is trying to give a new perspective in order to understand the reality of young villagers' migration. Theoretically, study on young people's migration from village to village has been carried out by Harahap and Ambarwati (2015), White (2018), and Chazali (2019). Some studies have explained that the social system of youth has a strong influence on agricultural development values. Nowadays, findings from the study on young people's migration from a village to a town are dominated by research related to natural resource access and the economic values of the agriculture like the ones studied by Rigg (2006), Harahap \& Ambarwati (2015), White (2018) and Chazali (2019). However, research concerning youth's migration from the perspective of how agricultural image is formed by a social system is still limited, one of which is the one carried out by Nugraha \& Supriatna (2020b) and Nugraha (2012) that focuses on explaining the position of parents and peers in forming a working image in the agricultural sector. To understand a complete role of social system, it is necessary to see how the youth watch television and the impacts on the working image in agricultural sector. The phenomenon about low participation of the youth in agricultural sector needs to be studied more comprehensively by considering the construction that is built by these young people (and their social system) in order to build agriculture. Therefore, it is important to see how the youth watch television and how they interpret the meaning of agricultural information on

Jurnal Komunikasi Pembangunan | Vol. 19 (01) 2021 | 28 
television. Basically, television has an important role in national development, including agricultural and rural development (Suri, 2019).

Based on the previous condition this research is aimed to see how the youth interpret agricultural performance on television. For further details, the questions of the research that the study is trying to answer are as follows: (1) What are the characteristics of the youth in Ciasmara Village, Pamijahan District, Bogor Regency? (2) What is the exposure of the youth in Ciasmara Village, Pamijahan District, Bogor Regency when watching television? (3) What is the perception of the youth in Ciasmara Village, Pamijahan District, Bogor Regency about agricultural information representation on television?

\section{RESEARCH METHODS}

This research was carried out in Ciasmara Village, Pamijahan District, Bogor Regency. Ciasmara Village has been selected because this village is one of the agricultural centers in Bogor Regency. Besides, in terms of location, Ciasmara Village is located in the hub of garment /textile areas which absorbs a lot of young labor. This research is a part of an enormous study about a heritage pattern of agricultural values, carried out from July 2019 to August 2020. The population of the research is young people aged between 15-24, unmarried, educated, and they come from farmer's family. According to the information obtained from Ciasmara Village data there are approximately 1290 young people taken as the research population. Thus, based on Neuman (2014) sampling method 120 of them have been chosen as the research samples. This research used post-positivism paradigm with a quantitative method and a quantitative-descriptive approach. The quantitative-descriptive approach in this research means an overview of young people who are exposed to television and their perception of agricultural information on television. A descriptive analysis used in this research is a descriptive tabulation consisting of frequency, percentage of young people, their exposure to television, and their perception of the representation of agricultural information on television. Data collecting techniques were carried out by questionnaires and also in-depth interview with some young people, their parents, and village officials in order to get complete quantitative findings.

\section{RESULTS AND DISCUSSION}

\section{Characteristics of young people in Ciasmara Village}

\section{Educational Level}

Education plays an important role in the context of the formation of identity and working aspiration of the young people. White (2012) and Nugraha \& Herawati (2015) said that education on one side can increase the young critical thinking, but on the other side it can make them set apart from the agricultural sector. In this research education is defined as a final formal education of the young people in Ciasmara Village at the time the research was conducted.

Table 1. Distribution of Respondents based on Educational Level

\begin{tabular}{ccc}
\hline Level of Education & Frequency (person) & Percentage (\%) \\
\hline D3/Undergraduate & 6 & 5 \\
Senior High School & 73 & 60.83 \\
Junior High School & 41 & 34.17 \\
\hline Total & $\mathbf{1 2 0}$ & $\mathbf{1 0 0}$ \\
\hline
\end{tabular}

This research is trying to identify the attitude of young people aged between $15-24$. Based on Table 1, it can be seen that 60.83 percent of young people in the research are of senior high school level, while 34.17 percent are junior high school level, and only 5 percent of D3 or Bachelor graduates. The high rate of young people of senior high school level is because since 2005 in Ciasmara Village there have been 2 high schools, namely Muhammadiyah High School in Pamijahan and Bumi Putera Vocational High School. According to the research by Nugraha \& Nugroho (2019) and Nugraha \& Supriatna 
(2020b), nowadays in Ciasmara Village there is a progress in education compared to the previous generation. This is because in the past the facilities available were only up to junior high school. If students wanted to continue their studies, they had to take a fifteen-kilometers distance from Ciasmara Village. Then in 2005 a school-equal-to-senior high school was established there. Up to now there have been two senior high schools, namely Muhammadiyah Pamijahan High School and Vocational High School Bumi Putera Saat in Ciasmara Village. In the meantime, the low number of young people in Ciasmara Village is due to the many people (especially the young) who decide to leave Ciasmara Village and migrate to towns to work in factories or to become mobile satay sellers. They usually work in the garment factories located in Dramaga, while those who decided to become satay sellers could sell as far as Bogor City, and even Jakarta. The study carried out by White (2012), indicated that on the one hand schools could improve competitiveness and human resource quality, but on the other hand schools become a factor that makes the process of transmission of agricultural knowledge from parents to children become inhibited, since young people must focus on their study first and on farming later.

\section{Respondents' age}

In this research, age is defined as the life expectancy of the youth in Ciasmara Village from the time they were born until the research was conducted. Operationally, this research sees age as the life expectancy of the youth in Ciasmara Village up to the research time.

Table 2. Distribution of Respondents' Data based on Age

\begin{tabular}{lccc}
\hline Age (years) & Age Category & Frequency (person) & Percentage (\%) \\
\hline $15-17$ & Mid teenagers & 46 & 38.3 \\
$18-21$ & Late teenagers & 39 & 32.5 \\
$>21$ & Early adults & 35 & 29.2 \\
\hline Total & & $\mathbf{1 2 0}$ & $\mathbf{1 0 0}$ \\
\hline
\end{tabular}

According to Nugraha (2012), with regard to the level of psychological development, respondents in this research were divided based on the level of psychological development. From Table 2 it can be seen that the number of the first group namely those aged between 15-17 years old or mid-teenagers respondens is 38.3 percent, the second group, aged between 18-21 years old or late teenagers is 29.2 percent, and the third group, more than 21 years old or early adults, is 29.2 percent. The results showed that respondents in this research were dominated by the youth aged between 15 and 17 years old. This is because the youth of Ciasmara Village at that age are still in senior high school and they have not migrated out of Ciasmara Village. On the other hand, generally the youth of Ciasmara Village aged 18 years old or more after graduating from senior high school would migrate and leave their village. As has been said by Nugraha \& Supriatna (2020a), the youth of Ciasmara Village after they graduate from senior high school choose to migrate to work as mobile satay sellers or to continue their studies.

\section{Sex}

In this research sex is defined as a biological condition of the youth in Ciasmara Village during the research.

Table 3. The Youth Attitude towards Employment in the Sector of Agriculture.

\begin{tabular}{lcc}
\hline Sex & Frequency (person) & Percentage (\%) \\
\hline Male & 74 & 61.67 \\
Female & 46 & 38.33 \\
\hline Total & $\mathbf{1 2 0}$ & $\mathbf{1 0 0 . 0 0}$ \\
\hline
\end{tabular}

Table 3 shows that there were 61.67 percent male respondents and 38.33 percent female respondents. This indicates that biologically most respondents of the research are males. This finding is not in line with the one carried out by Nugraha \& Supriatna (2020a) who found that females were more dominant 
than males. However, based on the results of in-depth interview, the higher number of male respondents found in this research is because there are so many young people in this village who are migrating to towns come back to their village due to the covid-19 case. There are some youths who have been laid off and there are some others who halt their business to wait until the condition in the place where they do business is improving. The youth consider their village, the place where they will spend the rest of their time because of its close kinship relationship, will be able to provide them with a good social security network. Based on the secondary data concerning the potential of Ciasmara Village, it is found out that in total the male population is higher than the female population.

\section{The exposure of the youth in Ciasmara Village to television}

\section{Frequency of watching television}

In this research, the frequency of watching television is defined as how often the youth watch television in one week over the past one month.

Table 4. Data Distribution of Respondents based on the Frequency of Watching Television

\begin{tabular}{lcc}
\hline Frequency of watching television & Frequency (person) & Percentage (\%) \\
\hline Once a week & 18 & 15.0 \\
Twice a week & 10 & 8.3 \\
Thrice a week & 18 & 15.0 \\
Everyday & 74 & 61.7 \\
\hline Total & $\mathbf{1 2 0}$ & $\mathbf{1 0 0 . 0}$ \\
\hline
\end{tabular}

From Table 4 it can be seen that the majority of the youth in Ciasmara Village watch television everyday can reach 61.7 percent, while 15 percent respondents watch television once a week and also thrice a week. Then there are 8.3 percent of respondents who watch television twice a week. The high frequency of the youth to watch television because at this time they study from home; thus, they relatively have more time to watch television. However, these young people do not watch television by themselves, but they are accompanied by their siblings or parents. There are some differences in the pattern of watching television between young males and young females. Young males prefer to watch football together with their father, while the girls tend to watch telenovela or electronic cinema with their sisters and mother. In the meantime, there are also some young people who do not watch television every day because they do not have time to watch the one they like since they have to succumb to their sisters or brothers and parents who want to watch television; thus, they prefer to hang out together with their friends. This finding is in line with what have been found by Nugraha \& Nugroho (2019), who said that the youth in the village lose their opportunity to watch television for the sake of their sisters or brothers, or even their parents. These young people can watch television only after people at home have gone to bed or when they can watch television together like watching football games or electronic cinema.

\section{Favorite Time to Watch Television}

In this research the favorite time to watch television is defined as the time that is mostly used by young people at Ciasmara Village to watch television.

Table 5. Data Distribution of Favorite Time to Watch Television.

\begin{tabular}{ccc}
\hline Favorite Time to Watch Television & Frequency (Person) & Percentage (\%) \\
\hline Morning $(07.00-10.00)$ & 13 & 10.83 \\
Noon $(11.00-14.00)$ & 12 & 10.00 \\
Afternoon $(15.00-18.00)$ & 22 & 18.33 \\
Evening $(19.00-21.00)$ & 73 & 60.83 \\
\hline Total & $\mathbf{1 2 0}$ & $\mathbf{1 0 0 . 0 0}$
\end{tabular}


Table 5 shows that most young people at Ciasmara Village (60.83\%) choose their favorite time for watching television in the evening. The second position is young people who their favorite time for watching television in the afternoon (18.33\%), and only about $10.83 \%$ and $10 \%$ young people who choose to watch television in the morning and at noon. This finding is in line with the previous research carried out by Nugraha \& Nugroho (2019) who said that young people in the village tend to watch television in the evening instead of daytime. The high percentage of young people who choose to watch television in the evening is due to the following reasons: (1) from morning to noon young people at Ciasmara Village have an activity like schooling, whether it is online or offline, and help their parents in the rice field. This finding is supported with the one described by Nugraha and Supriatna (2020) who said that young people at Ciasmara Village are still involved in helping their parents in the rice field in the stages of tilling the land and harvesting, while young females are mostly involved in delivering foods and preparing the foods for their parents. (2) young people at Ciasmara Village, males or females, tend to have their favorite program on television in the evening. The favorite program young people at Ciasmara Village always watch, among others, Bioskop (Trans TV), Big Movies (Global TV), Sinetron Ikatan Cinta (RCTI), and Give Away (Trans TV). This finding is in line with the one found by Jayawinangun \& Nugraha (2018) who said that young people in the village have the tendency to watch television and play games on the internet in the evening since in the morning they have their school activities or help their parents.

\section{Youth's Perception of Agricultural Information on Television}

The frequency of watching agricultural programs on television in the last one month. The frequency of watching agricultural programs is defined as young people's experience to watch television related to agricultural sector in the last six months.

Table 6. Distribution of Respondents based on the Frequency of watching Agricultural Programs

\begin{tabular}{lcc}
\hline Frequency of Watching Television & Frequency (Person) & Percentage (\%) \\
\hline Watching television & 66 & 55 \\
Never & 54 & 45 \\
\hline Total & $\mathbf{1 2 0}$ & $\mathbf{1 0 0}$ \\
\hline
\end{tabular}

Table 6 above shows that most young people at Ciasmara Village (66 persons) or about 55 percent admitted to have watched agricultural programs on television in the last six months. In the same period, however, there were 45 percent of the youth at Ciasmara Village who admitted not to have watched agricultural programs on television. Those who admitted to have watched agricultural programs on television such channel as Kompas TV, RTV or Elsinta TV or other programs such as Jejak si Gundul, Bocah Petualang, and Indonesiaku. These young people admitted that they seldom watched television programs that are merely related to agriculture. They generally watched agricultural content on the news or other programs such as Jejak si Gundul, Bocah Petualang, and Indonesiaku. Although there were special agricultural programs broadcasted on TVRI, they still cannot see it because of school and other activities in the morning. In order to understand their attitudes toward watching television, it is necessary to see how they interact with their peers, because the study carried out by Jaccard et al., (2005) found that close friends can influence how young people behave, including watching agricultural programs on television. The frequency of interaction with peers in agricultural sector will very much influence young people on deciding what programs to watch on television. Study carried out by Nugraha (Nugraha, 2012) found that young people who interact with peers in the agricultural sector have influenced young people's attitude towards watching agricultural programs on television.

The limited number of agricultural programs on television are also explained by Valdiani et al., (2017) in her research. This is due to a limited number of television stations that broadcast agriculture on television. Nugraha (2012) is also of the opinion that the television station that routinely broadcasts agricultural programs is TVRI (Television of Republic of Indonesia), whereas other television stations have not broadcasted routinely agricultural programs. Agricultural programs that young people often 
watch are Pelangi Desa (Village Rainbow), Salam Dari Desa (Greeting from Village), and Daerah Membangun (Building Area). Public Television stations like TVRI has an important role to broadcast agricultural and rural development in Indonesia through messages putting forward proximity content or message proximity. TVRI through its regional representatives is able to give agricultural and rural information tailored to the needs of its people (Atika et al., 2020). Television has an important position to distribute information, not only limited to urban areas but also rural areas, as has been found out by Akter \& Mezbah-ul-Islam (2016) who said that television has a central role in rural development in Bangladesh. Rural people in Bangladesh also experienced the same problem as those in Indonesia, where they tended to be illiterate with rural and agricultural information because there was no television station that specifically presented agricultural and rural programs.

Types of Agricultural information on television. In this research type of agricultural information is defined as a type of information that is often watched by young people at Ciasmara Village. In this research it was found out that about seven types of agricultural information that young people consider as the most watched on television. The information is as follows: cultivation, great harvest, harvest failure, pest attack, low-priced crops, and market difficulty, hydroponic development, agricultural technology and severe drought. From Table 7 it can be seen that 66 young people who watch agricultural programs on television (Table 6), agricultural information that is often watched by young people at Ciasmara Village is respectively, from the most watched until the least watched is information of cultivation, about 30.30 percent, information on harvest failure $(21.21 \%)$ information on great harvest $(18.18 \%)$, pest attack (15.15\%), low-priced harvest yield and difficulty in selling harvest yield (9.09\%), hydroponic development (3.03\%), agricultural technology (1.52\%), and drought $(1.52 \%)$.

Table 7. Distribution of respondents' data based on types of agricultural information young people watch

\begin{tabular}{lcc}
\hline Type of Agricultural Information & Frequency (\%) & Percentage (\%) \\
\hline Cultivation (chili, mushroom, corn, vegetables) & 20 & 30.30 \\
Harvest failure & 14 & 21.21 \\
Great harvest & 12 & 18.18 \\
Pest attack & 10 & 15.15 \\
Low-priced crops and market difficulty & 6 & 9.09 \\
Hydroponic development & 2 & 3.03 \\
Agricultural technology & 1 & 1.52 \\
Drought & 1 & 1.52 \\
\hline Total & 66 & 100.00 \\
\hline
\end{tabular}

Information about agricultural cultivation is very diverse. According to young people there is a lot of information on agricultural cultivation, among others, chili, mushroom, rice, vegetables, fruits, and corn. They gained information about this cultivation from the news and another program such as Jejak si Gundul. In the meantime information related to great harvest, harvest failure and pest attack were often obtained from the news on television. Valdiani et al., (2017) explained that television plays an important role in establishing an image of agriculture, especially to young people in the village. Information about agriculture that was found in this research varied a lot from the one that encourages agricultural development such as agricultural cultivation, great harvest, hydroponic development, agricultural technology until information that discusses problems faced by farmers such as harvest failure, pest attack, market difficulty and drought. Study carried out by Nazari (2002) explained about the importance of television in building an agricultural sector in Iran. Based on the explanation, initially farmers in the research location did not know how to use technology and how to eradicate pests effectively; however, after an agricultural program was broadcasted on television which focused on how to control pest attack, they became successful.

\section{Young people's affection towards information of agriculture on television}


In this research young people's affection towards information of agriculture on television is defined as young people's views on agricultural program that they watch on television. In Table 8 it can be seen that approximately 46.97 percent of young people who watch agricultural programs on television (66 persons, see Table 6) are of the opinion that agricultural programs that they watch on television tend to give negative messages, as much as 30.30 percent of young people consider agricultural programs on television give neutral messages, and as much as 22.73 percent of young people think that agricultural programs on television tend to be positive.

Table 8. Distribution of data about young people's affection towards information of agriculture on television

\begin{tabular}{lcc}
\hline $\begin{array}{c}\text { Young people's affection towards information of } \\
\text { agriculture on television }\end{array}$ & $\begin{array}{c}\text { Frequency } \\
\text { (person) }\end{array}$ & $\begin{array}{c}\text { Percentage } \\
(\boldsymbol{\%})\end{array}$ \\
\hline Negative messages & 31 & 46.97 \\
Neutral messages & 20 & 30.30 \\
Positive messages & 15 & 22.73 \\
\hline Total & $\mathbf{6 6}$ & $\mathbf{1 0 0 . 0 0}$ \\
\hline
\end{tabular}

Young people at Ciasmara Village tend to think that agricultural programs on television are negative because the information delivered is mainly concerned with the failure in agriculture. As has been put forward by one respondent, Adit (23 years old), he said that news on television often reports harvest failure, pest attack, drought and low-priced agricultural product. An accumulative representation of agriculture in a negative way can establish a negative image of agriculture in the eyes of young people in rural areas. Furthermore, the representation of a negative agriculture does not only appear in the news related to agriculture but also in the primetime news, where farmers (including animal farmers) often become the objects who are helpless, whose house is uninhabitable, having a lot of debts, and more often they are described as "marginal people". Television as one of the socialization agents of young people plays an important role to build their perception, attitude, and behavior towards an object. Darling (2007) in their research have put television as one of the subsystems that play a role to build young people. Repeated television programs will be able to instill some values of an object to young people.

In the context of this research, negative representation of agriculture that is performed repeatedly and massively can make young people in the rural areas build a negative view on the jobs in the agricultural sector. Nugraha (2012) in his study found that exposures to agricultural programs on television are related to young people's attitude towards agricultural sector. This means that the more often young people watch agricultural programs on television, the more affected regeneration in the agricultural sector. Valdiani et al., (2017) also stated that the appearance of agricultural programs that is closely related to poverty will give impact on agricultural image in the eyes of young people in rural areas. However, besides information of agriculture that tends to be negative, this research also found that 30.30 percent of young people who watch agricultural news on television tend to be neutral. This means that young people consider agricultural programs that they watch on television do not tend to deliver negative or positive messages. Young people see that messages of agriculture in the programs they watch at the same time give positive as well negative information, so that they tend to be neutral towards the information they receive. Meanwhile, there were 22.73 percent of young people who consider that agricultural programs on television tend to give negative messages such as agricultural cultivation, hydroponic and great harvest in the pandemic era. Apart from the relatively small number of young people who are exposed to positive agricultural information, in this covid-19 pandemic era, there appear some youth movements to become farmers on social media, especially YouTube. This can become a trigger to counteract the information of agriculture that tends to be negative on television. Young people's movements in the agricultural sector nowadays start to appear in line with the increasing awareness to ensure the agricultural regeneration in rural areas in Indonesia and awareness to build food security in urban areas. Concern about negatively repeated information of agriculture on television will give a bad impact of agricultural image in the eyes of young people, and 
this will take them away further from the jobs in the agricultural sector. Similar finding from the research carried out by Jannat (2018) showed that radio and television play an important role to establish agriculture in Bangladesh. If information of agriculture tends to be negative, it will give a bad impact on the farmer's innovation adoption ability, and it can even make an agricultural setback; on the other hand, if the information of agriculture is positive, farmers' productivity will increase further.

News about agricultural information that is negative tends to deconstruct agriculture accumulatively and in no time will make young people uninterested to stay in the village and they will tend to move out of the village. A negative image of agriculture that is produced by television makes young people think that farming is a complicated job and it has no future. This will encourage young people to leave their villages and migrate to towns. Some studies related to deconstruction of agricultural values have been discussed by Nugraha (2012) and (Akatiga \& White, 2015). They found that mass media often describe rural areas and farmers are not promising and poor. Mass media make young people are actively related to global ideas and young people's lifestyle that make them see farming and rural areas differently.

\section{CONCLUSION}

Young people at Ciasmara Village in this research majority are of senior high school level, aged ranging between 15-17 years old, and mostly males. The majority of young people at Ciasmara Village watch television in the evening together with other members of families and watch television every day. The high percentage of young people who choose to watch television in the evening is due to some reasons, among others, (1) from morning to noon young people at Ciasmara Village have school activities, offline as well online (virtual), and help parents work in the rice field. (2) young people at Ciasmara Village admit that in the last six months, both males and females, tend to have a favorite pastime in the evening. Young people at Ciasmara Village admit that in the last six months they have watched farming programs on television. The farming programs they have watched are related to farming cultivation, harvest failure, pest attack, and great harvest. Young people at Ciasmara Village tend to consider information of agriculture on television contains negative messages such as harvest failure, pest attack, and drought. News or information of agriculture that is negative tends to deconstruct agriculture accumulatively in a certain time and can make young people uninterested anymore to stay in the village and prefer to move out of their village. A negative image of agriculture produced by television makes young people see that farming is a complicated job and has no future. This encourages them to leave their village and to migrate to towns.

The research findings can a new perspective in understanding the complex issues of young people's migration from rural areas to urban areas or from farming sector to non-farming sector. Theoretically, this study can give a contribution of knowledge that in understanding young people's migration it is important to know the concept of young people's identity and how young people's identity and working aspiration are formed. Conceptually, there are a variety of social subsystems that can form young people's identity, as has been discussed in the previous researches, namely parents, peers, school system, mass media and the state political system. This research found that perceptively majority young people see television tends to present negative farming content, even though there are also some young people who consider that some information on farming is neutral and positive. Practically, the research findings can become a basis for encouraging to rehabilitate the agricultural image carried out by media mass or social media. For example, encouraging community's journalism to package farming positively and hopefully; however, it must be accompanied by tackling empiric problems related to existing farming problems. In this pandemic era as a matter of fact there appear some movements carried out by young people in urban areas as a response to food security in the pandemic era. This situation needs to be conserved so that young people's movement advocation in farming will be kept until regeneration of working in the agricultural sector happens.

\section{REFERENCE}

Akatiga, \& White, B. (2015). Would I like to be a farmer? - Inside Indonesia. In Inside Indonesia. https://www.insideindonesia.org/would-i-like-to-be-a-farmer-2 
Akter, R., \& Mezbah-ul-Islam, M. (2016). Television as a Medium of Information for Rural Development in Bangladesh: A Case Study of Dinajpur District. 10th Convention PLANNER2016, 42(January). https://ir.inflibnet.ac.in:8443/ir/handle/1944/2046

Atika, Chandrabuwono, A. B., \& Maulina, N. (2020). Ekologi Media Televisi Publik berdasarkan Program Informasi Lokal di Kalimantan Selatan The Media Ecology of Public Television based on Local Information Programs in South Kalimantan. 18(02), 152-162.

BPS. (2013). Pedoman Pencacah Sensus Pertanian 2013.

BPS. (2017). Statistik Pemuda Indonesia 2017.

Chazali, C. (2019). the Intergenerational Dimensions of Land Transfer Among Smallholder Farm Households in Indonesia (Issue November).

Darling, N. (2007). Ecological Systems Theory: The Person in the Center of the Circles. Research in Human Development, 4(3-4), 203-217. https://doi.org/10.1080/15427600701663023

Harahap, R. A., \& Ambarwati, A. (2015). Tanah Untuk Penggarap? Penguasaan Tanah dan Struktur Agraris di Beberapa Desa Penghasil Padi. Jurnal Analisis Sosial Akatiga, 19(1), 1-30.

Huijmans, R. (2010). Migrating Children, Households , and the Post-Socialist State Department of Geography. Durham University.

Jaccard, J., Blanton, H., \& Dodge, T. (2005). Peer influences on risk behavior: An analysis of the effects of a close friend. Developmental Psychology, 41(1), 135-147. https://doi.org/10.1037/0012-1649.41.1.135

Jannat, S. T. (2018). Role of Radio and Television in Agricultural Development Role of Radio and Television in Agricultural Development 1.

Jayawinangun, R., \& Nugraha, Y. A. (2018). Penggunaan Internet Dan Media Sosial Orang Muda Di Pedesaan. Wahana, 24(2), 1-14.

Nazari, M. R. (2002). Impact of Television on Rural. University Malay.

Neuman, W. L. (2014). Social Research Methods: Qualitative and Quantitative Approaches. In Teaching Sociology (Vol. 30, Issue 3). https://doi.org/10.2307/3211488

Nugraha, Y. A. (2012). Hubungan antara Orang Tua, Teman Sepermainan, dan Media Massa dengan Sikap Pemuda terhadap Pekerjaan di Sektor Pertanian (Kasus Desa Cipendawa dan Desa Sukatani, Kecamatan Pacet, Kabupaten Cianjur). Bogor Agricultural University.

Nugraha, Y. A., \& Herawati, R. (2015). Menguak realitas orang muda sektor pertanian di perdesaan. Seri Penelitian Akatiga, 19(1).

Nugraha, Y. A., \& Nugroho, D. R. (2019). RURAL YOUTH BEHAVIOR IN WATCHING TELEVISION (Case Study Rural Youth in Ciasmara Village Pamijahan Sub-District, Bogor Regency). Jhss (Journal of Humanities and Social Studies), 3(1), 32-36. https://doi.org/10.33751/jhss.v3i1.1098

Nugraha, Y. A., \& Supriatna, R. A. (2020a). PERAN TEMAN SEPERMAINAN DALAM MEMBENTUK SIKAP PEMUDA PEDESAAN TERHADAP PEKERJAAN DI SEKTOR PERTANIAN PADI ( Kasus Pemuda di Desa Ciasmara, Kecamatan Pamijahan Kabupaten Bogor ). Jurnal Ilmiah Agribisnis, 5(1), 1-10.

Nugraha, Y. A., \& Supriatna, R. A. (2020b). Pola Komunikasi Ritual Orang Tua-Anak Dalam Pewarisan Pengetahuan Dan Afeksi Terkait Pekerjaan Di Sektor Pertanian Padi. Commed: Jurnal Komunikasi Dan Media, 4(2), 208. https://doi.org/10.33884/commed.v4i2.1591

Rigg, J. (2006). Land, farming, livelihoods, and poverty: Rethinking the links in the Rural South. World Development, 34(1), 180-202. https://doi.org/10.1016/j.worlddev.2005.07.015

Supriatna, R. A., \& Nugraha, Y. A. (2020). Menguak Realitas Praktik Sedekah Bumi di Desa Ciasmara Kecamatan Pamijahan Kabupaten Bogor. Jurnal Penelitian Sosial Ilmu Komunikasi, 2(1), 43-59.

Suri, D. (2019). Pemanfaatan Media Komunikasi dan Informasi dalam Perwujudan Pembangunan Nasional. Jurnal Komunikasi Pembangunan, 17(2), 177-187. https://doi.org/10.46937/17201926848

Valdiani, D., Nugraha, Y. A., \& Siregar, M. R. . (2017). Attendance Of Mass Media And Parents In Defining The Value Of Agriculture In The Eyes Of Rural (Case Study of Rural Youth at 
Horticulture Center in Cianjur Regency). Jhss (Journal of Humanities and Social Studies), 1(1), 28-34. https://doi.org/10.33751/jhss.v1i1.370

White, B. (2012). Agriculture and the Generation Problem. Agriculture and the Generation Problem, 43(6). https://doi.org/10.3362/9781780447421

White, B. (2018). Marx and Chayanov at the margins: understanding agrarian change in Java. The Journal of Peasant Studies, 45(5-6), 1108-1126. https://doi.org/10.1080/03066150.2017.1419191

White, B. (2020). IFAD RESEARCH SERIES 48 Rural Youth, Today and Tomorrow. In SSRN Electronic Journal. https://doi.org/10.2139/ssrn.3567742 